\title{
STUDENT CREATIVITY BOOSTING WITH INNOVATIVE DIGITAL ACTIVITIES TO ENHANCE STUDY COURSE QUALITY
}

\author{
Ieva Rudzinska \\ Latvian Academy of Sport Education \\ Anisoara Pop \\ Mirela Dredetianu
}

University of Medicine and Pharmacy, Tîrgu Mureş, Mureş, România

\begin{abstract}
The article aims to introduce some digital activities for ESP (English for Specific Purposes) courses and show the effect of their introduction on the quality of study process in an ESP course and on its results. With the help of ESP course quality evaluation model (Rudzinska, 2011) ESP course quality is evaluated along the following criteria: study course clarity, adequacy, cooperation, individual work, variety, and deep approach. Quantitative and qualitative research methods are used to investigate the improvement of study process quality due to the introduction of digital tools. The base of the research are the students of a Latvian higher education institution (HEI) (Institution A) and a Romanian HEI (Institution B), who from 2008/2009 to 2011/2012 studied ESP (Business English and Sports English) with the help of such digital tools as Bighugelabs, Piclits, Glogster, Textivate, Freemind and Wikipedia article creation. In Institution B student satisfaction level with the use of digital tools was surveyed through a 5-point Likert scale questionnaire and oral interviews. In Institution $A$ the students freely reflected on their learning experience with the help of the mentioned digital tools. The results in both HEIs show high student satisfaction with the introduction of digital tools: in Institution B slightly satisfied were 15\%, moderately satisfied: 10\%, very satisfied: $58 \%$, and extremely satisfied: $15 \%$ of respondents. Qualitative analysis showed that ESP course quality due to the introduction of digital tools improved in relation to quality criteria, summarized in the mentioned quality evaluation model (clarity, adequacy, cooperation, individual work, variety, and deep approach), as well as in relation to other quality criteria: accessibility, availability, novelty, variety, creativity, an opportunity to be proud about the results of the work done; the weaknesses were due to lack of accessibility (Internet connection in my village is too slow), lack of creativity (I'm not very creative) and complicated techniques of digital tool application.
\end{abstract}

Keywords: English for Specific Purposes (ESP), quality assurance in language learning, ESP course quality criteria, digital tools in language learning, higher education institutions (HEIs).

\section{Introduction}

European Common Framework for learning, teaching and assessing languages $(\mathrm{CEF}, 2011)$ outlined main characteristics of qualitative language learning, several researchers developed a list of instruments, with the help of which can be evaluated the quality in one study course in general, and in English for Specific Purposes (ESP) study courses in particular (Lasnier, 2003; 
Meder/Iske, 2009; Rudzinska, 2011). With the help of Rudzinska instrument the quality of an ESP course is evaluated with the help of such criteria as clarity, adequacy, cooperation, individual work, variety, and deep approach. One of the ways of increasing study course quality is through the use of information and communications technology (ICT). Different digital activities can be employed in ESP courses in order to motivate students, exploiting their creativity and imagination. Student involvement and learning outcomes are higher when students discover rather than when they are taught ESP course concepts (Pop, Rudzinska, Dredetianu, 2013). New technology allows introducing study activities that would not be possible otherwise (Oliveira, 2013), even developing a new kind of literacy, seen as a social practice based on texts (Street, 2003). However, a list of studies have emphasized that access to technology itself does not provide enhanced teaching or change in teaching practices (Blikstad-Balas, 2013). Digital generation uses ICT in a very superficial way, without assessing their reliability (Oliveira, 2013). Therefore, the impact of digital tools on study course quality is an open research issue.

The main purpose of the article is to reflect on the introduction to students some digital tools for ESP courses, present findings on attitudes the students have towards their use in ESP courses and to evaluate the effect of the introduction of digital tools on the quality of ESP course process and results.

The base of the research: 86 students of a HEI from Latvia (Institution A) and Romania (Institution B), who from 2008/2009 to 2011/2012 studied ESP (Business English and Sports English) with the help of such digital tools as Bighugelabs Piclits, Glogster, Textivate, Freemind and writing for Wikipedia.

Methods used: action research was carried out in both institutions: exploring and using of digital tools, during which both students and lecturers were researchers, who exploited their critical thinking skills. Student observation was carried out during classes, student survey: afterwards, and finally - content analysis of student created documents. In Institution B student satisfaction level was surveyed through a 5-point Likert scale questionnaire and oral interviews, based on open-ended questions. In Institution A students freely reflected on their learning experience with the help of digital tools. Qualitative research methods were used to investigate the improvement of study process due to the introduction of digital tools.

Digital tools. The use of digital tools in both institutions started with poster making with Bighugelabs and Piclits. Students advertised entities they were well acquainted with such as their HEI, campus, library, and hostel. Later was introduced Glogster - an educational platform, enabling the inclusion of text, photos, videos, sounds, drawings and data attachments and used for the creation of online multimedia posters.

To activate student work with texts, in both institutions ESP teachers used Textivate, which allowed uploading texts and automatic generation of text-based exercises: "fill in the blanks", "scrambled sentences", a.o. By clicking the button 
"Textivate now" the original text was divided into the desired number of chunks or paragraphs, which students afterwards dragged back into place. The added value of digital exercise in comparison to traditional one is that it can be embedded on class sites for permanent out-of-class access and thus is available to students for further practice (Pop, Rudzinska, Dredetianu, 2013). The main drawback of Textivate is that it allows using only short texts (up to 500 words), besides, a lot of further applications, like printing out of the rearranged text and receiving instant feedback require registration, and are not for free.

To enhance terminology acquisition digital mind maps were created in Institution A, using Freemind software. Al Jarf (Al Jarf, 2010) suggests using mind mapping in ESP for term presentation, their modeling, and for guided practice. Mind maps can be of different types, including phonological, morphological, syntactic and semantic ones. In the Program of Physiotherapy in Institution A students benefited from semantic mind maps, focusing on human body systems, among them circulatory, digestive, nervous, respiratory, a.o. systems; phonological mind maps, focusing on terms, having common vowels; morphological mind maps, reflecting Latin plurals (schema-schemata, a.o.) and showing opposites of different medical notions (internal-external, inversioneversion, a.o.).

Time and effort consuming undertaking in Institution A was writing for collaborative global encyclopedia Wikipedia. The goal of Wikipedia, launched only in 2001, is to cover existing knowledge, avoiding the creation of new knowledge. Wikipedia is continually created and updated: people of all ages and cultural and social backgrounds can write Wikipedia articles, add information, cross-references (wiki links) or citations within Wikipedia's editing policies and to an appropriate standard (Wikipedia. 2013).

Wikipedia is becoming increasingly popular globally and it is the most visited on educational and reference material (Raine and Tancer, 2007). From a philosophical point of view Jandric (Jandric, 2010) asserts that Wikipedia creates a virtual anarchist society, based on knowledge network. Those, writing to the world, participate in the creation of collective intelligence.

Szesnat (Szesnat, 2006) research shows that educational use of Wikipedia is at least twofold: it can be used as a database for knowledge and as a teaching tool. Wikipedia uses reliable sources - information must be supported by footnotes and general references, therefore students engage in correct citation practice. The main drawback of Wikipedia in Tardy's (Tardy, 2010) opinion is that students use it as a primary research source of information. Oliveira has revealed a paradox in young people attitude to Wikipedia as a source of knowledge: although young people consider Wikipedia to be unreliable source of information (more credible sources of information are books), Wikipedia is declared to be their primary source of information (Oliveira, 2013). Also Blikstad-Balas investigations has revealed "a didactic challenge: the students' preferred knowledge source ... is a knowledge source they are not intended or in 
many cases not allows to use" (Blikstad-Balas, p.2.).

Oliveira (Oliveira, 2013) admits that participation in writing to Wikipedia is difficult, because writers hardly understand what an encyclopedic article is and what knowledge people consider as valid; besides, it requires a lot of technical skills. However, Oliveira also points out that writing for Wikipedia "demands motivation, effort, dedication, learning, stuff that school teaches by means of educational communication" (Oliveira, 2013, p.7)., and finally concludes that writing for Wikipedia promotes critical thinking and synthesis, it is an activity oriented towards transformation of individuals, multiliteracy and culture of citizenship, and those, who have done it, "will be better equipped for the world we live on" (Oliveira, 2013, p.7).

Tardy (Tardy, 2010) suggests that writing to Wikipedia can be successfully employed for educational reasons as middle stage of writing in higher education, first stage being writing personal essays, and third: writing formal academic texts. In Tardy's opinion Wikipedia offers an excellent forum for students to begin confronting challenges of academic writing: research, citation, conventions and style.

Students can benefit a lot from research before writing to Wikipedia from exploring Wikipedia articles as to their content and wording, and from gathering reliable information for their articles. In Institutions A writing for Wikipedia was carried out in several stages, suggested by Tardy (Tardy, 2010):

1. Students discuss what Wikipedia is, and share their experience in using it.

2. Students print out an article about famous Latvian sportsmen from English and Latvian versions of Wikipedia, and bring it to class.

3. Students are divided into groups according to their sport, they share the articles they have brought and discuss what kind of information is included in Latvian and English Wikipedia articles, what common headings are used, what kind of information is included in footnotes and in wiki-links, what specialized language or jargon is used, etc.

4. Lecturer demonstrates how easy it is to edit articles; afterwards students edit an article or several articles.

5. Students prepare for writing: with the help of a Fact sheet gather all necessary information, put copied passages in quotation marks and tag the sources.

6. Students prepare an outline for article, paraphrasing gathered information.

7. Students produce first draft in the form of clear and coherent text, using lettered tags to include reference to sources. Finally, the created articles are revised and peer reviewed.

As to their quality Wikipedia articles rank from well-written, comprehensive articles to so-called stubs and orphans. Stubs are good short articles, sometimes just a few sentences, but should provide some useful 
information. "Most Wikipedia's articles begin as stubs and ideally grow into well-written, comprehensive articles." (Wikipedia, 2013). An article is called an orphan, if no other articles relate to it.

\section{Results}

In Institution B students used such digital tools as Bighugelabs Piclits, Glogster and Textivate. Quantitative analysis of student response in Institution B showed high student satisfaction with the introduction of innovative on-line tools: slightly satisfied were $15 \%$, moderately satisfied - $10 \%$, very satisfied $58 \%$; extremely satisfied $-15 \%$ of respondents.

Qualitative analysis of student response in Institution B showed that ESP course quality due to the introduction of digital tools improved in relation to quality criteria, summarized in the mentioned quality evaluation model: clarity, adequacy, cooperation, individual work, variety, and deep approach, the only exception is the criterion of clarity: students have not stated that digital tools increase the clarity of study process. Student answers allowed identifying some other quality criteria, which are not incorporated in the mentioned model: accessibility, availability, novelty, variety, creativity, an opportunity to be proud about the results of the work done; the weaknesses of digital tool application were due to lack of accessibility (Internet connection in my village is too slow), lack of creativity (I'm not very creative) and complicated techniques of digital tool application (lack of adequacy).

In institution A students used Bighugelabs, Freemind and writing for Wikipedia. During study years 2011/2012 and 2012/2013 students wrote or edited articles about 30 Latvian sportsmen. Content analysis of the documents showed that among them are representatives (players and coaches) of 17 team and individual sports, mostly basketball (6) and football (4) players. Student choice is not a surprise, since basketball and football are among most popular sports in the Republic of Latvia, besides they are obligatory sports in Institution $\mathrm{A}$, and a lot of students practice them from early age.

Analysis of student created Wikipedia articles showed that usually they were stubs. Besides, a lot of articles were orphans. To improve their articles students were suggested to introduce links to the page from related articles, or to edit one or more other articles, searching Wikipedia for other pages referring to the subject of the article, then turn those references into links.

Table 1 presents statistics on student created Wikipedia articles. 
SOCIETY. INTEGRATION. EDUCATION. Volume I

Table 1. Statistics on student created/edited Wikipedia articles

\begin{tabular}{|c|c|c|c|c|c|}
\hline $\begin{array}{l}\text { Sports person } \\
\text { surname, name }\end{array}$ & $\begin{array}{l}\text { Years of } \\
\text { birth (and } \\
\text { death) }\end{array}$ & Sport & $\begin{array}{l}\text { Creators } \\
\text { (students), years } \\
\text { of creation }\end{array}$ & $\begin{array}{l}\text { Write } \\
\text { (W)/ } \\
\text { edit (E) }\end{array}$ & $\begin{array}{l}\text { Still exists } \\
(+) / \text { does not } \\
\text { exist(-) / label }\end{array}$ \\
\hline Alfrēds Krauklis & 1911-1991 & $\begin{array}{l}\text { basketball } \\
\text { player and } \\
\text { coach }\end{array}$ & J.B., 2012 & $\mathrm{~W}$ & + \\
\hline Andris Biedriņš & 1986 & basketball & J.S., 2012 & $E$ & + \\
\hline Jānis Timma & 1992 & basketball & A. Š., 2012 & $\mathrm{E}$ & + \\
\hline Armands Šksēle & 1983 & basketball & J. Z., 2012 & $\mathrm{E}$ & + \\
\hline Andrejs Šel̦akovs & 1988 & basketball & A.S., 2012 & $\mathrm{~W}$ & $+/$ stub \\
\hline Žanis Peiners & 1990 & basketball & L.L., 2013 & $\mathrm{~W}$ & - \\
\hline Dāvis Straupe & 1992 & ice hockey & I.V., 2012 & W & - \\
\hline Aldis Trukšāns & 1990 & football & A.T., 2012 & $\mathrm{E}$ & - \\
\hline $\begin{array}{l}\text { Andrejs } \\
\text { Pereplotkins }\end{array}$ & 1984 & football & O.Z., 2012 & $\mathrm{E}$ & + \\
\hline
\end{tabular}

The analysis of student response concerning the introduction of on-line activities in ESP course in Institution A showed the improvement of course quality along all quality criteria, summarized in Rudzinska quality model. An example of qualitative analysis of student response is presented in Table 2.

Full qualitative analysis of student response and student observation in Institution A showed the following strengths of the introduction of digital tools: the course was more attractive, more oriented toward deep learning, individual work and cooperation (receiving feedback from peers and Wikipedia editors). Besides, course clarity also increased, because Freemind allowed clear representation of vast terminology mind maps. Weaknesses mostly were due to rather complicated techniques of digital tool application.

Table 2. Example of qualitative student response analysis in institution A

\begin{tabular}{|l|l|l|l|}
\hline Respondent & Digital tool & Student response & $\begin{array}{l}\text { Quality } \\
\text { criterion }\end{array}$ \\
\hline $\begin{array}{l}\text { A.B., male, } \\
2013\end{array}$ & FreeMind & $\begin{array}{l}\text { I liked the new program, because acquiring } \\
\text { it will also be useful in other study courses }\end{array}$ & $\begin{array}{l}\text { deep } \\
\text { learning }\end{array}$ \\
\hline $\begin{array}{l}\text { Male, 20, } \\
2013\end{array}$ & $\begin{array}{l}\text { Freemind, } \\
\text { Bighugelabs } \\
\text { more diverse... }\end{array}$ & $\begin{array}{l}\text { attractivene } \\
\text { ss }\end{array}$ \\
\hline $\begin{array}{l}\text { female, } \\
\text { Year 2 }\end{array}$ & Wikipedia & $\begin{array}{l}\text { to write an article for Wikipedia is not easy, } \\
\text { but it is also not impossible }\end{array}$ & adequacy \\
\hline $\begin{array}{l}\text { female, } \\
\text { Year 2 }\end{array}$ & Wikipedia & $\begin{array}{l}\text { if you want to write a good article, you'll } \\
\text { need patience and time }\end{array}$ & $\begin{array}{l}\text { deep } \\
\text { learning }\end{array}$ \\
\hline $\begin{array}{l}\text { A, female, } \\
20, \text { Year } 2\end{array}$ & Wikipedia & $\begin{array}{l}\text { it was difficult, because information many } \\
\text { times was deleted, it was also hard to } \\
\text { understand how to put links and insert } \\
\text { chapter titles }\end{array}$ & $\begin{array}{l}\text { not } \\
\text { attractive }\end{array}$ \\
\hline $\begin{array}{l}\text { K., male, } \\
\text { Year 2 }\end{array}$ & Freemind & $\begin{array}{l}\text { as } \text { Inew terminology, it was only the } \\
\text { repetition for me }\end{array}$ & $\begin{array}{l}\text { not } \\
\text { attractive }\end{array}$ \\
\hline
\end{tabular}


Common conclusion can be drawn that digital activities can enhance course quality, but can as well provide no improvement. Evidence shows that digital activities could be too easy for some students and still too complicated for others; interesting for some students, and boring for others, etc. In order not to rely only on serendipities in the improvement of course quality with digital tools, activities should be carefully designed and applied.

\section{References}

Al-Jarf, R. (2010). Mind mapping, Presentation, given at International language conference "The importance of learning professional foreign languages for communication between cultures", Celje, Slovenia: University of Maribor, $6 \mathrm{p}$.

Blikstad-Balas, M. (2013). Students' Attitudes Towards Wikipedia as a Knowledge Source in School. Paper presented at ECER 2013, Creativity and Innovation in Educational Research, Available from URL: http://www.eera-ecer.de/ecer-programmes/ conference/8/contribution/21636/ (accessed on September 23, 2013).

Jandric, P. (2010). Wikipedia and education: anarchist perspectives and virtual practices. Journal for Critical Education Policy Studies, vol.8. no.2, pp. 48-73, Available from URL: www.jceps.com/PDFs/08-2-02.pdf (accessed: 24.09.2013).

Lasnier, J.C. (2003). Quality, Version 2003, Available from: URL http://www.quiltnetwork.org, 2003 (accessed on May 5, 2007).

Meder, E., Iske, S. (2009). Quality assurance by RQCC: how quality is attributed to the relation between learner and e-learning environment. Proceedings of EDULEARN09 Conference, Barcelona, Spain, July 6-8, 2009.

Oliveira, L.R., et.al. (2013). Data Is A Built Thing: (De)Constructing The Curriculum Through Wikipedia Writing. EduLearn 2013 July, Barcelona, Spain, Virtual participation.

Raine, L. \& Tancer, B. (2007). Wikipedia users. Washington, DC: Pew Internet \& American Life Project. Retrieved from URL: http://pewinternet.org/Reports/2007/Wikipediausers.aspx ((accessed on September 10, 2013).

Rudzinska, I. (2011). Promocijas darbs, Latvijas Universitāte: Riga, 2011.

Street, B., 2003. What's „new” in New Literacy Studies? Critical approaches to literacy in theory and practice 2003, Current Issues in Comparative Education, Vol. 5(2).

Szesnat, H. (2006). Who Knows? Wikipedia, Teaching and Research. SBL Forum 4.9 (2006). Available from: URL http://www.sbl-site.org/Article.aspx?ArticleId=603, (accessed on July 20, 2012).

Tardy, C.M. (2010). Writing for the World: Wikipedia as an Introduction to Academic Writing, English Teaching Forum, Vol. 48, No.1, 2010, 12-20.

Wikipedia. 2013. Wikipedia: About. Available from: URL http://en.wikipedia.org/wiki/ Wikipedia: About, August 2013 (accessed: 5.08.2013). 